\title{
WHEN JUSTICE FAILS: JURISDICTION AND IMPRECATION IN ANCIENT EGYPT AND THE NEAR EAST
}

\author{
By JAN ASSMANN
}

In this comparative study of ancient belief and practice, the Egyptian evidence is analysed first, then placed in the wider context of the Near East. It is argued that, while laws and curses are both ways of preventing damage by threatening potential evildoers with punishment, the difference lies in the fact that in the one case punishment is to be enforced by social institutions, in the other by divine agents. Curses take over where laws are bound to fail, as when crimes remain undetected and when the law itself is broken or abandoned. The law addresses the potential transgressor, the curse the potential law-changer who may distort or neglect the law. The law protects the social order, the curse protects the law. These points are illustrated by extensive quotation from Egyptian and Near Eastern texts.

\section{Egyptian Curses}

IN a recent contribution, Harco Willems ${ }^{1}$ proposed a new interpretation for a genre which J. A. Wilson had called 'curses and threats' and rubricised under the general heading of 'Rituals, incantations'. ${ }^{2}$ Willems holds that these texts, or at least a considerable part of them, do not belong to the domain of magic or religion, but to that of legislation and jurisdiction. He takes punishments such as burning, ${ }^{3}$ and even cooking ${ }^{4}$ - which have generally been held to refer to infernal punishments in the hereafter, belonging more to the history of hell than that of jurisdiction ${ }^{5}$ as legal sanctions against desecration of monuments which were actually executed in ancient Egyptian legal practice. To prove his case, he compares the punishments which potential desecrators or violators of monuments are threatened with, with penalties occurring in undoubtedly legal texts such as the Neferhotep decree and the Tod inscription of Sesostris I, where burning appears as a legal punishment. ${ }^{6}$ The Neferhotep decree even fixes this penalty for crimes like trespassing on land declared 'holy' by strolling around while not on duty. Given such jurisdiction, it is indeed plausible that tomb-owners threatening trespassers with burning would rather refer to that law than to religious concepts about the hereafter.

1 JEA 76 (1990), 27-54.

${ }^{2}$ In J. B. Pritchard, Ancient Near Eastern Texts Relating to the Old Testament ${ }^{3}$ (Chicago, 1955), 326-8. For an extensive treatment of the subject, see now the dissertation by Scott N. Morschauser, Threat Formulae in Ancient Egypt, Baltimore, 1987 (UMI: Ann Arbor, 1987).

${ }^{3}$ Siut III, ed. E. Edel, Die Inschriften der Grabfronten der Siut-Gräber (Opladen, I984), fig. 5, pp. 25-37: 'Their flesh will burn together with that of the criminals, they having been turned into ones who do not exist'; for context see below.

${ }^{4}$ Siut IV, lines 79-80, Edel, op. cit. I 20-7: 'He shall be cooked together with the criminals, whom god has cursed; his city-god shall abominate him, his fellow-citizen shall abominate him'; for context see below.

${ }^{5}$ E. Hornung, Altägyptische Höllenvorstellungen (Leipzig, I 968).

${ }^{6}$ A. Leahy, JESHO 27 (1984), i 99; id., JEA 75 (1989), 45 n. (n). 
But Willems somewhat misconstructs the alternatives. The alternative to legal prosecution is not 'mere threats, that we need not take at face value' (p. 38), but imprecation or cursing. The distinction between laws and curses, jurisdiction and imprecation, is not that the one expresses a certainty and the other 'vague hopes or expectations', but that the one refers to the agency of social institutions and the other to the intervention of divine, or demoniac-in any case transcendent-powers. It is only to people living in an 'enlightened' and institutionally secure age such as ours that the efficiency of social institutions such as police and law-courts seems much more 'certain' (i.e. real and reliable), than that of metaphysical agency. In the ancient world, the situation was at least different, if not inverse. Willems' otherwise brilliant argumentation suffers from this form of anachronism and an ensuing underrating of the tradition and importance of cursing. It seems therefore necessary, in order to complement his arguments and to demonstrate the real importance of his findings, briefly to outline a more adequate historical reconstruction, distinguishing the respective functions of laws and curses, legislative and imprecative texts.

Jurisdiction establishes a nexus between norm and sanction on the one hand, and action and consequence on the other. If an action implies violation of a law, then as a consequence there will be a penalty. The nexus between crime and penalty is to be defined by jurisdiction and to be enacted by judicative and executive institutions, i.e. by society and the state. This is what I call "connective justice.' Connective justice provides and protects the link between action and consequence, doing and faring. The following diagram illustrates this link by using the symbol c ('causation') for a relation where what is on the left side 'causes' what appears on the right side: ${ }^{8}$

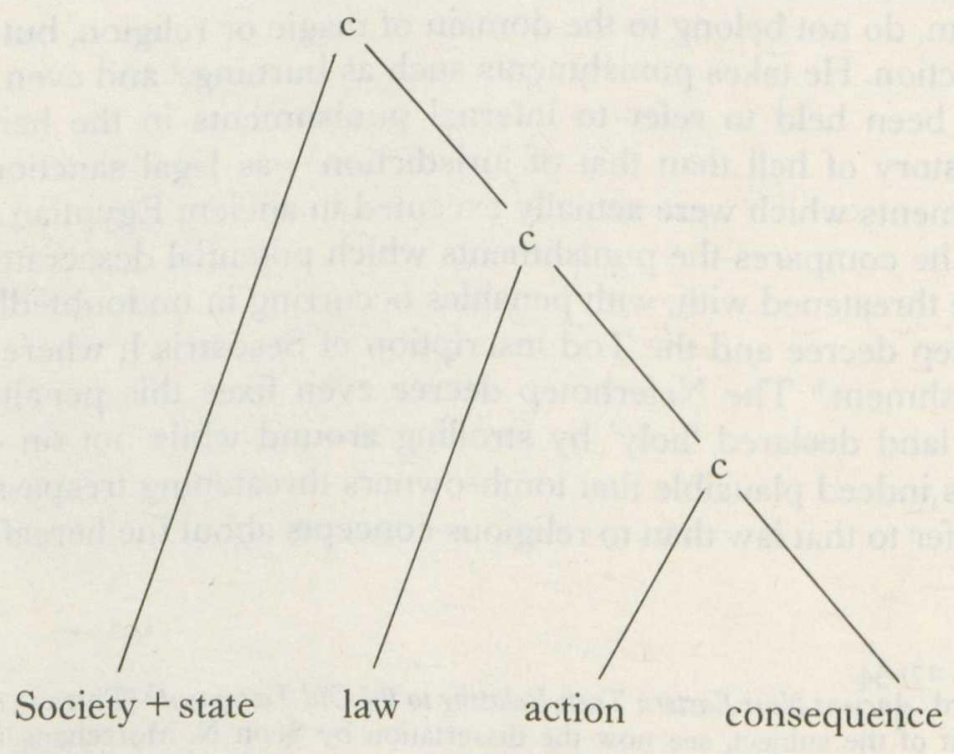

But there are two cases where connective justice is bound to fail: (I) if the crime is committed secretly and there is no accuser, and (2) if the law as a whole is not properly enacted, or is altered or even completely done away with by society and/or the state. In

${ }^{7}$ J. Assmann, Ma'at. Gerechtigkeit und Unsterblichkeit im alten Ägypten (Munich, 1990), 66-9, 283 ff.; id., History and Memory 2.I (I990), 5-33, esp. 2 I-6.

${ }^{8}$ Cf. my article in W. K. Simpson (ed.), Religion and Philosophy in Ancient Egypt (New Haven, I 989), 64. 
these cases, other agencies must take care of the nexus between action and consequence, agencies which I shall call, for want of a better term, 'metaphysical':

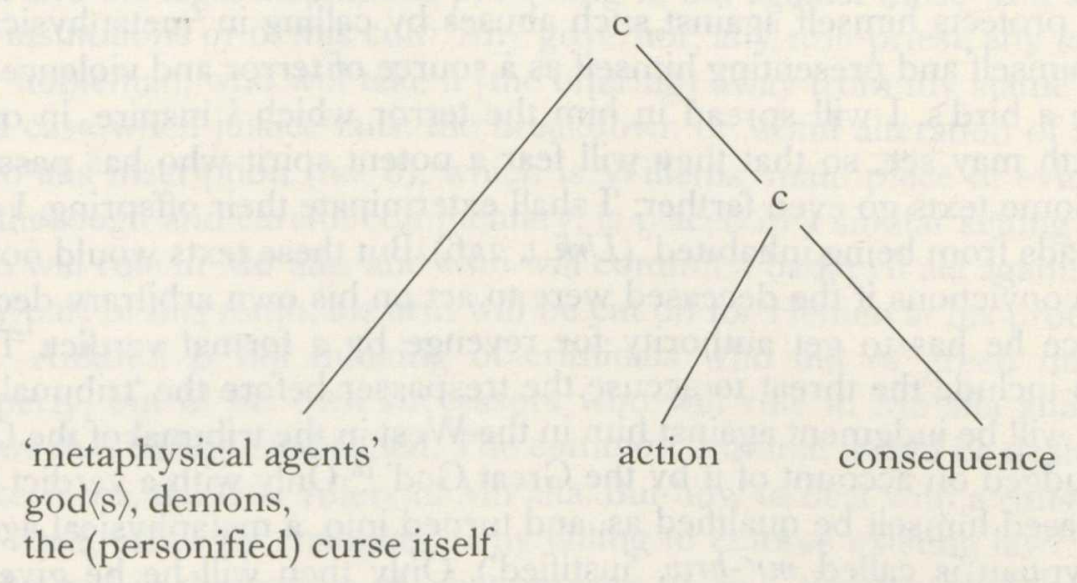

This is the formal structure of a curse or imprecation. A curse triggers 'metaphysical agents' to bring about the consequence of a given action. It establishes a link between crime and penalty which is independent of socio-political institutions and therefore quasi-automatic. ${ }^{9}$ Oaths and curses extend the range of efficiency of 'connective justice' beyond the sphere of legal institutions into the sphere of divine maintenance of cosmic order. They presuppose and confirm a world-view where both cosmic and social order follow the same principle of retribution. Causation, in this world-view, assumes the more concrete form of retribution. The coherence and continuity of the world depends not on 'causality' but on 'connective justice'. This explains how the Egyptian term Maat could refer both to cosmic and social order, truth and justice. ${ }^{10}$

Disbelief in metaphysical agents will cause a decline in the tradition of cursing, ${ }^{11}$ disbelief in the functioning of socio-political institutions will have the opposite effect. The most obvious difference between legal sanctions and curses is to be seen in the fact that curses are complemented by blessings, whereas sanctions have no positive complement. No law-code ever provides a reward for those who keep the law, whereas imprecation texts as a rule balance curses against a trespasser by blessings for the obedient. The reason for this asymmetry is simple: a judge does not dispose of rewards for every loyal citizen, a 'metaphysical agent' does.

Secret criminality and breakdown of connective justice provide the two cases where jurisdiction stops and imprecation takes over. Desecration of tombs belong to both

\footnotetext{
${ }^{9}$ This touches upon the problem of 'magic', i.e. the idea of a mechanical link between cause and effect, established by some ritual device, and in our case by the pronunciation of a curse (cf. the literature quoted by W. Schottroff, Der altisraelitische Fluchspruch (Neukirchen, I969), I6 n. 2). But this is not how inscriptional curses work. They require metaphysical (not 'mechanical') agency and therefore do not suggest a distinction between magic and religion.

${ }^{10} \mathrm{Cf}$. Assmann, Ma at, chapters I and 6. Hans Kelsen, a specialist in constitutional law, showed 50 years ago that social and judicial concepts of retribution almost universally precede scientific and abstract concepts of causality: H. Kelsen, Vergeltung und Kausalität, written 1941, appeared in English as Society and Nature, (Chicago, 1943), and in German (Den Haag, 1947). For the concept of causality, see also A. Malamat, $V T 5$ (I955), I-I 2.

${ }^{11}$ This, as R. Wagner informs me, seems to be the case in ancient China, where cursing in these functions is virtually unknown.
} 
classes. Secret criminality is involved in desecration caused by a visitor who enters a tomb in his state of impurity' or 'without being pure'12 because nobody except the person himself can tell whether he has 'eaten what a spirit abominates' ${ }^{13}$ or not. ${ }^{14}$ The tomb-owner protects himself against such abuses by calling in 'metaphysical agency' in the form of himself and presenting himself as a source of terror and violence: 'I shall grab his neck like a bird's, I will spread in him the terror which I inspire, in order that the living on earth may see, so that they will fear a potent spirit who has passed on to the West... .' ${ }^{15}$ Some texts go even farther: 'I shall exterminate their offspring, I shall prevent their farmsteads from being inhabited' (Urk. I, 256). But these texts would not correspond to Egyptian convictions if the deceased were to act on his own arbitrary decision. Before using violence he has to get authority for revenge by a formal verdict. Therefore the imprecations include the threat to accuse the trespasser before the 'tribunal of the Great God': 'There will be judgment against him in the West in the tribunal of the Great God' or 'He will be judged on account of it by the Great God'. ${ }^{16}$ Only with a verdict in his favour will the deceased himself be qualified as, and turned into, a metaphysical agent of justice (what in Egyptian is called $m_{3}$-hrrw, 'justified'). Only then will he be given the power $(\mathrm{shm})$ to use revenge. ${ }^{17}$

Some inscriptions from the late Fifth and Sixth Dynasties invoke crocodile and snake against him 'who will do anything against "this"'.

The crocodile against him in the water,

the snake against him on earth

who will do anything against 'this'. ${ }^{18}$

But a later text shows that this menace, too, might refer to the transformed deceased himself. In one of the Middle Kingdom texts which Willems proposes to interpret as legal edicts we read: 'I shall be against him as a crocodile in the water, as a snake on the earth and as an enemy in the necropolis. ${ }^{19}$ Here, the same images refer to the retaliating activities of the deceased as an effective spirit, who is able (as the 'transformation spells' of mortuary literature show) to transform himself into any form he wishes, including snake

${ }^{12} m$ cbw $f$. The latter translation, which takes $m$ to be not the preposition 'in' but the negation $j m$, has been proposed by Edel, Altägyptische Grammatik, II (Rome, I964), §I I I 2 Anm., and has the great advantage of disposing of an otherwise unattested word cbw, 'impurity', having the same orthography as cbw, 'purity', but opposite meaning. Cf. also Edel, MDAIK I3 (I944); but see now E. Blumenthal, in U. Verhoeven and E. Graefe (eds.), Religion und Philosophie im Alten Agypten (Louvain, I 99 I), 47-56.

${ }^{13}$ E.g. Ankhmahor, Urk, I, 201-2; Wilson, op. cit. 327 (d).

${ }^{14}$ Here belongs also the concept of 'immaterial evil', i.e. evil not in the form of manifest deeds but of thought and speech, against which Pharaoh is protected by execration rites; see my contribution to the Festschrift Leclant (in press), 'Spruch 23 der Pyramidentexte und der Schutz Pharaos vor Herz und Mund seiner Feinde'.

${ }^{15}$ From the inscription of Khentika, T. G. H. James, The Mastaba of Khentika called Ikhekhi (London, I 953), pl. v.

${ }^{16}$ Edel, MDAIK I3, 5-15. Cf. also G. Fecht, Der Vorwurf an Gott in den Mahnworten des Ipuwer (Heidelberg, I972), I $36 \mathrm{f}$,, who comments on the particular 'Gewalttätigkeit' and 'Selbstherrlichkeit' of these formulae, which express an unmistakable 'Unabhängigkeitsdrang' and 'Unabhängigkeitsbewußtsein'.

${ }^{17}$ For curses implying litigation, see Morschauser, op. cit. $224^{-4}$. Such a lawsuit is frequently alluded to and even elaborately depicted (spell I49) in the Coffin Texts, cf. R. Grieshammer, Das Fenseitsgericht in den Sargtexten (Wiesbaden, I 970), I 31-48.

${ }^{18}$ Urk. I, 23, I I-16, similarly Urk. I, 226, 13-14. On the mastaba of Meni and its date, see A. Scharff, MDAIK 8 (1 939), I 7-33.

${ }^{19}$ Heqaib stela no. 9, Willems, $\mathcal{F E} A 76,34$. 
and crocodile, and to summon an enemy to the tribunal in the hereafter. This menace is directed not against any ordinary visitor who might secretly or overtly violate the mortuary cult and the legal institutions protecting it, but against those who are in charge of these very institutions or of this cult: 'Any governor, any $w a b$-priest, any $k a$-priest, any scribe or any nobleman, who will take it [the offering] away from my statue'. This refers to the second case when justice fails: the breakdown or wilful alteration of legal institutions. The Mo'alla inscription (no. 8), which is Willems' main piece of evidence and is given a very thorough and careful commentary, is placed in a similar setting: 'As regards any ruler who will rule in Mo'alla, and who will commit a bad, evil act against this coffin, and again any part of this tomb, his arm will be cut off for Hemen at his procession from the district...' Ankhtifi is not thinking of criminals who out of greed might rob his funerary property, but of his own successors who will rule in Mo'alla and who might neglect the laws that he has established. The common criminal would be dealt with by the law and its executors, the later rulers of Mo'alla. But how to deal with a ruler who invalidates the law itself, either by changing or by failing to enforce existing law? ${ }^{20} \mathrm{He}$ will be opposed by the god in the course of what appears to be a 'this-worldly' enactment of a 'that-worldly' law-court, on the occasion of the processional festivals of Hemen. ${ }^{21}$ In terms of genre, Ankhtifi is evidently doing the same thing as his predecessors, the tomb-owners of the Old Kingdom: he is protecting his tomb by dreadful curses, threatening a trespasser with cruel punishment. But in terms of form, he is not cursing but legislating. He institutes a kind of 'sacred law' which he thinks will be safe against abuse by his successors, because it is not enacted by political institutions but by the god himself during his processional appearance. This follows from Willems' convincing arguments, and it follows also from a very simple observation: the absence of blessings. Ankhtifi's inscription has to be classified not as a curse, but as a decree. But the originality of this procedure and the absolutely exceptional character of this text are obscured as soon as one follows Willems in taking this as a model case and in interpreting all the other imprecation texts in its light. The exceptional step taken by Ankhtifi must be explained in the context of the exceptional historical situation, when the political and juridical institutions of the centralistic pharaonic state had collapsed and the gods had to fill the breach.

It is not quite clear to what extent the protection of private tombs in Egypt fell within the scope of the state and its institutions. It is very probable that the state held a much larger share in this responsibility than was the case in other countries. For in Egypt, the erection of monumental tombs also seems to be controlled by the state, at least in the capital necropoleis. In his still unsurpassed study on the protection of funerary property in ancient Egypt, Sottas devoted a long chapter to 'mesures édictées par le roi fondateurbienfaiteur'. ${ }^{22}$ The most interesting document, in this respect, is Koptos decree 'R' for the benefit of the funerary monuments of a certain Idi, in which king $D m \underline{d}$-jb-tswj lays down a list of punishments closely resembling what a trespasser is threatened with in curses: excommunication from society in this world ('nhw, 'the living') and the other world (3hw $m \underline{h r t} n t r$, 'spirits in the necropolis'), loss of property, imprisonment under the 'verdict'

${ }^{20}$ Cf. Nauri decree ed. F. Ll. Griffith, $\mathscr{F E A ~ I 3 ~ ( 1 9 2 7 ) , ~ p l . ~ x l i i i , ~ l i n e s ~ I 0 7 - 1 4 , ~ w h e r e ~ O s i r i s ~ i s ~ i n v o k e d ~ t o ~}$ punish those who fail to respond to violations.

${ }^{21}$ In this I agree completely with Willems, who refers on p. $30 \mathrm{n}$. (c) to the parallel in CT I, 74: 'Your enemy's foreleg is cut off for you' and stresses the possibility of an earthly enactment of a kind of divine judgement (p. $3^{6}$ n. 38 ).

${ }^{22} \mathrm{H}$. Sottas, La préservation de la propriété funéraire (Paris, I 9 I 3 ). 
$(m d w)$ of the king, Osiris and the city-god. ${ }^{23}$ With this text, the borderline is crossed (or taken down) which normally separates the realm of social institutions from that of divine agency, the range of laws from that of curses. It seems that with this decree a tradition was started which Ankhtifi in his description continued or usurped. ${ }^{24}$

It seems therefore desirable to sketch, however briefly and incompletely, the outlines of the history of that genre to which the Ankhtifi text belongs, albeit as a borderline case or as an exception: the genre of 'monumental imprecation'. I think it even necessary to extend this survey beyond the borders of the pharaonic world because Egypt obviously shared a much more general tradition. A survey of other examples from the First Intermediate Period and the early Middle Kingdom (all already quoted by Willems) shows that all of them invoke the intervention of gods and spirits (highlighted by italics in the following translations). The punishments typically consist of (I) deprivation of burial; (2) bodily destruction (e.g. by burning); (3) exclusion from divine communication (offering) and social memory, a kind of 'excommunication' including outlawry. ${ }^{25}$ All these punishments might reappear in royal edicts as legal sanctions. ${ }^{26}$ But here they are clearly meant as the destructive consequence of a curse laid upon the violator, and not as the announcement of legal prosecution ('trespassers will be prosecuted'). For all of these inscriptions contain blessings for him who will act piously.

As regards any nome governor, any son of a man, any nobleman or any civilian, who will fail to protect this tomb and its contents, his god will not accept his white bread, he will not be buried in the West, and their flesh will burn together with that of the criminals, they having been turned into ones who do not exist. ${ }^{27}$

As for any rebel who will rebel and who will plan in his heart to commit blasphemy against this tomb and what it contains, who will destroy the inscriptions and damage the statues in the tombs of the ancestors in the necropolis of Siut and the temple of the lord of Ra-qert without being afraid of the tribunal which is therein, he shall not be glorified in the necropolis, the seat of the glorified spirits, his property shall not exist in the necropolis, his children shall be expelled from their tombs, he shall be an enemy of the glorified spirits, whom the lord of the necropolis does not know, his name shall not be called among the spirits, his memory shall not be among those living on earth, water shall not be poured for him, offerings shall not be given to him on the wag-feast and any other beautiful feast of the necropolis. He shall be delivered to the tribunal, his city god shall abominate him, his relatives shall abominate him, his farm shall fall to fire, his house to the devouring flame. Everything which comes forth from his mouth, the gods of the necropolis shall pervert it. ${ }^{28}$

As for any rebel and any adversary who will commit destruction in spite of what he has heard: His name shall not exist, he shall not be buried in the desert, he shall be cooked together with the damned, whom god has cursed; his city-god shall abominate him, his fellow-citizen shall abominate $\operatorname{him}^{29}$

${ }^{23}$ Koptos R, ed. R. Weill, Les Décrets royaux de l'Ancien Empire (Paris, I 912 ), pl. iv. I.; Sottas, op. cit. 90-7; W. Schenkel, Memphis-Herakleopolis-Theben (Wiesbaden, I 965), 23 f; Morschauser, op. cit. 243-5.

${ }^{24}$ Another case in point, not dealt with by Willems, is the decree of Nubkheperre Intef (ed. W. Helck, Historisch-Biographische Texte der 2.Zwischenzeit und neue Texte der I8.Dynastie (Wiesbaden, I 975), 73 f. In this text, curse and punishment go very close together. The king prescribes the punishment of a certain criminal-which has to be considered as an act of jurisdiction-and threatens future kings who would show mercy to this man or to his descendants - which has to be considered as an act of cursing.

25 The verdict of outlawry, i.e. deprivation of legal protection, appears rather in royal than in private texts; cf. e.g. PT I 278-I279c, where the term niš or $n s$, 'to expel', is used.

${ }^{26}$ Cf. especially Koptos Decree R (n. 23).

27 Siut III, Edel, Grabfronten, fig. 5, pp. $25^{-37}$.

${ }^{28}$ Siut III, Edel, op. cit., fig. 7, pp. $37-66$

${ }^{29}$ Siut IV, lines $79^{-80}$, Edel, op. cit. $120-7$. 
As for anybody who will not recite this, he shall fall to the anger of his city-god, and to the slaughter of the king. He shall not be remembered among the spirits and nevermore shall his name be mentioned on earth; he shall not be buried in the West, he shall be burned together with the damned, since Thoth has condemned him; his face shall be spat at. ${ }^{30}$

As for anybody who will displace this stela from the tomb which I have built, he will not stand before Thoth and Maat shall not judge him. ${ }^{31}$

During the New Kingdom, imprecation formulae seem almost to disappear from tombs, but appear on other kinds of monuments such as statues, graffiti, and stelae, especially those recording private and royal donations. Few of them predate the Amarna revolution and there is a conspicuous increase in curses after it. This has to be seen within the wider context of Egyptian ideas about 'divine impact on human affairs'. Unlike Griffiths, ${ }^{32}$ I am not of the opinion that these ideas were typical of all periods of Egyptian history, but think that the New Kingdom and especially the post-Amarna age marks a profound transformation of Egyptian beliefs concerning divine intervention in human life. Morschauser also sees in the increase and different formulation of maledictions in Ramesside texts 'a shift, or change in the outlook of the Egyptians towards the ordering of their world, and the intervention of the divine in mundane affairs'. ${ }^{33}$ The new ideas find expression in a variety of new genres and institutions, such as stelae containing psalms of penitence and thanksgiving, ${ }^{34}$ biographies $^{35}$ and royal inscriptions ${ }^{36}$ narrating cases of divine intervention, and oracular texts. Central to these ideas is the concept of divine wrath; only now does the term $b i w$ assume this specific meaning. ${ }^{37}$

Typical of this new style of cursing is a formula, in which divine vengeance is apportioned to a triad of gods: ${ }^{38}$

As to anyone who shall be deaf to this decree, Osiris shall pursue hirn, Isis his wife, and Horus his children, and the great ones, the lords of the Holy Land, will make their reckoning with him. ${ }^{39}$

As to anyone who shall speak against it, Amon-Re, king of the gods, shall pursue him to destroy him, Mut shall pursue his wife and Khonsu his child, (so that) he shall hunger, he shall thirst, he shall become weak, and he shall suffer. ${ }^{40}$

[And as to] any people in the whole land to whom any person belonging to the House of Minmus'a-Rira has come saying ['a certain...] interfered [with me] and took my ox; or he took my ass, ${ }^{41}$ or he took my goat or anything which is stolen from people,' or 'such a one, the inspector,

${ }^{30}$ Tomb at Hasaya, Late Period, ed. Edel, op. cit. I 90 f.

${ }^{31}$ Louvre C r 08 ; P. Pierret, Recueil d'inscriptions inédites, II (Paris, I878) I; Sottas, op. cit. 55 f.; G. Möller, Das Dekret für Amenophis Sohn des Hapu (Berlin, I 9 I o), 943, Anhang No. 4.

${ }^{32}$ J. G. Griffiths, in J. R. Baines et al. (eds.), Pyramid Studies and Other Essays, presented to I.E.S. Edwards (London, 1988), 92-102.

${ }^{33}$ Op. cit. 277.

${ }^{34}$ For a fairly comprehensive collection of these texts in German translation, see my Ägyptische Hymnen und Gebete (Zürich, 1975), nos. I 47-200.

${ }^{35}$ See especially inscriptions in Theban tombs 194 and 409 , id. ib., nos. 172 and 173 .

${ }^{36}$ E.g. the Qadesh inscriptions of Ramesses II, see Th. von der Way, Die Textüberlieferung Ramses' II. zur Qades-Schlacht (Hildesheim, 1984), and the Israel Stela of Merenptah, see H. Sourouzian, Les monuments du roi Merenptah (Mainz, I 989 ), $167 \mathrm{ff}$.

${ }^{37}$ See J. F. Borghouts, in R. J. Demarée and J. J. Janssen (eds.), Gleanings from Deir el-Medina (Leiden, I 982$), \mathrm{I}-70$.

${ }^{38}$ For more examples, see Morschauser, op. cit. 286 f., 293, 296-8.

${ }^{39}$ After Wilson, op. cit. 328 (h); cf. S. Schott, Kanais. Der Tempel Sethos' I. im Wâdi Mîa (Göttingen, I 96 I), I $58 \mathrm{f}$. Similar curses appear in Theban inscriptions which are expressions of 'popular religion', see A. I.

Sadek, Popular Religion in Egypt during the New Kingdom (Hildesheim, 1987), 242-4.

${ }^{40}$ Steindorff, Aniba, I, pl. I I I.

${ }^{41}$ Following A. H. Gardiner, $7 E A 38$ (1942), 32. 
has taken my man by capture to do some work,' and they fly not at his word to have his opponent brought in haste in order to try him, Osiris Khentamenthes, the owner of the person, the owner of the goods, shall pursue him and his wife and his children to blot out his name, to annihilate his soul, to prevent his corpse from resting in the necropolis. ${ }^{42}$

With the multiplication of donations (or their monumental records) in the Third Intermediate Period, curses become very common. I limit myself to one example which surpasses the rest in length and variety: an inscription purporting to be a copy of a foundation document of the funerary temple of the sage Amenhotep son of Hapu:

As for the general or military scribe who will follow after me and who will find the $k a$-chapel falling into ruin together with its male and female servants who are cultivating the fields for my endowment, and shall take away a man therefrom in order to put him to any business of Pharaoh or any commission on his own behalf, or if another will trespass on them and will not answer on their behalf: he shall be exposed to the destruction of Amun..., he shall not let them enjoy their office of royal scribe of the army, which they received on my behalf. He shall deliver them to the fire of the king on the day of his anger. His Uraeus shall spit fire on their heads, annihilating their bodies and devouring their flesh, they becoming like Apophis on the morning of New Year. They shall capsize in the ocean that it may hide their corpses. They shall not receive the dignity of the righteous; they shall not eat the offering cakes of the 'cavern-dwellers' (the deceased in their tombs); one shall not libate for them water from the river; their son shall not be installed at their place; their wives will be raped while their eyes see it; the superiors shall not set foot $(t s)$ in their houses as long as they are upon earth; the leaders of the two sides shall not introduce them, nor shall they hear the words of the king in the hour of gladness. They shall belong to the sword on the day of destruction, they shall be called enemies; their bodies shall be consumed, they shall hunger without bread, and their bodies shall die. If the vizier, overseer of the treasury, chief overseer of the estate, superintendent of the granary, high priests, divine fathers, and priests of Amun, to whom has been read this edict, issued for the $k a$-chapel of...Amenhotep, shall not show solicitude for his $k a$-chapel, the edict shall touch them, and them especially.

But if they shall show solicitude for the $k a$-chapel, with the male and female servants who are cultivating the fields for my endowment, then all favour shall be shown them. Amon-Re, king of gods, shall reward them with prosperous life. The king of your day, shall reward you as he rewards... There shall be doubled for you office upon office, you shall receive from son to son and heir to heir. They shall be sent on as messengers, and the king of their day will reward them. Their bodies shall rest in the West after I I o years, doubled to you shall be the mortuary oblations likewise. ${ }^{43}$

It is near the end of the New Kingdom that 'obscene' curses appear among these formulae. In the decree for Amenhotep occurs the idea that the trespasser will see his wife raped before his eyes. Even more common in this genre of literature (especially on donation stelae) is the strange idea that the trespasser himself, together with his wife, will be sexually abused by a donkey, ${ }^{44}$ which must have been considered a particularly destructive blow against the personality of the culprit: ${ }^{45}$

${ }^{42}$ F. Ll. Griffiths, $7 E A$ i 3 (1927), 205, pl. xliii.

${ }^{43} \mathrm{C}$. Robichon and A. Varille, Le temple du scribe royal Amenhotep fils de Hapou (Cairo, I 936), 3-4; BAR II, $\$ \S 925$ f.; Möller, Das Dekret für Amenophis, 932-48; Morschauser, op. cit. 307-1 3 .

${ }^{44}$ Morschauser records 9 instances, see op. cit. $130^{-2}, 301-3,342-5$.

${ }^{45}$ Rape by a donkey: cf. W. Spiegelberg, $R T 25$ ( 1903 ), I 90 ff. Spiegelberg adduces some more examples of this formula, which appears to be fairly common in the Twenty-second to Twenty-fourth Dynasties; the earliest example, however, is a Ramesside graffito from Deir el-Bahari: Sadek, Popular Religion, 244; cf. also Sottas, Préservation, I 49-50, I 53, I65-8; A. H. Gardiner, FEA 26 (I 940), 23-9; J. G. Griffiths and A. A. Barb, Journal of the Warburg and Courtauld Institutes 22 (1959), 367-71. Some examples are discussed by J. J.

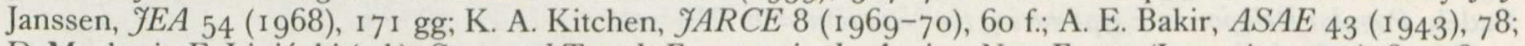
D. Meeks, in E. Lipiński (ed.), State and Temple Economy in the Ancient Near East, II (Louvain, I 979), 625-6. 
As for him who will make this endure, his son shall endure in his place, one after the other, his name shall not perish in eternity. But as for him who will remove them, the power of Neith will be against him in all eternity, his son shall not remain in his place, the donkey shall abuse him, his wife and his children. He shall go to the fire from the mouth of Sakhmet and to the... of the lord of All and all the gods; he who will destroy this donation for Neith, his property will be destroyed, his tomb will burn and not receive his children. Beware of Neith... ${ }^{46}$

The donkey reminds us of the snake and crocodile which the tomb owner of the Old Kingdom threatened to mobilize against a trespasser, albeit in the guise of his own agency as an 'effective spirit'. But here the animal seems to be a manifestation of the god Seth, who is appealed to in much the same way as the devil in Christian curses.

\section{Near Eastern Curses}

As far as the technique and genre of monumental cursing is concerned, Egypt shares a tradition which is common to many countries of the ancient Mediterranean world and the Near East. ${ }^{47}$ In this broader context, the affinity between jurisdiction and imprecation seems even closer than in Egypt, because curses (and blessings) appear not only on monuments but also in legal texts, viz. in treaties and boundary stones. ${ }^{48}$ The distinction between law giving and cursing is, however, very neatly drawn. As in Egypt, cursing complements criminal prosecution in those cases where justice is bound to fail: secret criminality and alteration of law. Among the Mesopotamian law-books, two of the texts preserved contain an imprecatory section: that of Lipit-Ishtar and that of Hammurapi. But the blessings and curses do not belong within the main body of laws and sanctions. They are clearly set apart in the form of an epilogue, with a clear predominance of curses. What these two texts have in common, as against the other law codes, is that in both cases a stela is involved. The Lipit-Ishtar code is preserved on clay tablets purporting to be the copy of a stela, and the epilogue refers to that stela, ${ }^{49}$ while the code of Hammurapi is actually preserved on a stela. ${ }^{50}$ The other Mesopotamian codes, which do not use or mention a monumental form of recording, do not contain an epilogue or imprecatory

\footnotetext{
${ }^{46}$ Stela of T3.f-nht, in Athens, ed. Spiegelberg, $R T$ 25, $190 \mathrm{ff}$;; R. el-Sayed, Documents relatifs à Saïs et ses divinités (Cairo, I975), 37-8, 43, pl. 7 .

${ }^{47}$ A. Parrot, Malediction et violation des tombes (Paris, I939); F. Pomponio (ed.), Formule di maledizione della Mesopotamia preclassica (Brescia, I990). For the concept of divine agency, see the important study by B. Albrektson, History and the Gods. An Essay on the Idea of Historical Events as Divine Manifestations in the Ancient Near East and in Israel (Lund, 1967 ).

${ }^{48}$ J. Pedersen, Der Eid bei den Semiten (1914), esp. 64-107; A. A. B. Mercer, JAOS 34 (I915), 282-309; B. Landsberger, Altorientalische Studien B. Meissner (1 928-9), 295-321. For boundary .stones (kudurru), cf. Pomponio, op. cit. $65-78$. A very specific context for imprecation is supplied by the custom of safeguarding written tablets by adding a colophon containing curses against potential mistreatment of the document; see G. Offner, 'A propos de la sauvegarde des tablettes en Assyro-Babylonie', Rev. d'Ass. et d'Arch. 44 (I950), 135-43, and Pomponio, op. cit. I03-5.

${ }_{49} \mathrm{R}$. Borger, in O. Kaiser (ed.), Texte aus der Umwelt des Alten Testaments, I, fasc. I = R. Borger, et al., Rechtsbücher (Gütersloh, I 982), 30 f:: 'The day on which I established justice in Sumer and Akkad, I verily erected this stela. May he be given a long life who will not commit bad actions against it, who will not destroy what I erected, who will not efface its inscription and not write his own name upon it. May he lift his neck to heaven in Ekur and may the radiant front of Enlil from heaven return his look; but who will commit bad actions against it, who will destroy or store away what I erected, who will change its place, efface its inscription, write his own name upon it or let another do it, be he a king, or a priest [...] may he flee...(a series of curses follows).

${ }^{50}$ Borger, loc. cit. $39 \mathrm{ff}$.
} 
catalogue. This shows that the blessings and imprecations belong, not to the act of lawgiving, but to that of stela-erecting. The parallels for the epilogues in the codes of LipitIshtar and Hammurapi are to be found not in law-books but on monuments and in treaties. Thus we read on a statue of Gudea of Lagash, several centuries earlier:

Whosoever will change the decree (and) will violate the decision - Anu; Enlil; Ninkhursag; Enki of just speech; Sin of irresistible name; Ningirsu, lord of the weapon; Nanshe, mistress of the Indub magazine; Nindar, the hero king; the mother of Lagash, the pure Gatamdu; Baba, the first-born of Anu; Inanna, the mistress of the battle; Utu, the lord of light; Khendursag, the herald of Sumer; Igalima; Shulshagana; Ninmar, the first-born of Nanshe; Dumuziabzu, the mistress of Kinunir; my (personal) god Ningizzida shall change his destiny; in that day he shall be slain like an ox; he shall be seized in his strength like a wild bull; the throne which he has built shall be cast to the dust; the will of the gods shall be directed towards the destruction of his inscription (and) his name; his name shall be removed from the temple of his god and from his inscription; his god shall not look on the affliction of his people; the rain of the sky shall be kept away from him; the water of the earth shall be kept away from him. A no-name shall have precedence over him. During his reign the corn shall be low (?); that man shall be there...like somebody who has done evil to a just man; he shall not be released. In the destruction (coming) from the gods the country will learn to recognize the power of the lord Ningirsu. ${ }^{51}$

The style of Mesopotamian curses, however, is very different from the Egyptian ones. The main difference lies in the concept of divine intervention. In Egypt, this is rather unspecific, the only specification applying, in the Ramesside age, to triads where the god is to pursue the man himself, the goddess his wife and the,child-god his children. In Babylonia, on the other hand, the deities each represent intervention in a specific sphere of human existence, such as lifetime, destiny, health, prosperity, intelligence, procreation, burial, social and political order etc. The idea of divine impact on human life seems so central to Mesopotamian religion, that the defining aspects and qualities of the deities are derived from the sphere of activity rather than from cosmology or mythology.

The imprecatory section of Hammurapi's epilogue outweighs its few blessings ( 3 lines of blessings, I oo lines of curses!). ${ }^{52}$ It proves beyond doubt that cursing has to be considered, much more so in Mesopotamia than in Egypt, as a highly elaborated technique and an important literary genre. ${ }^{53}$ In this section, Io particular gods and then the totality of the gods are invoked to take care of the trespasser,

who did not heed my words which I wrote on my stela, and disregarded my curses, and did not fear the curses of the gods, but has abolished the law which I enacted, has distorted my words, has altered my statutes, effaced my name inscribed thereon and has written his own name...

Enlil, the supreme god, is invoked to incite revolts, bring misfortune, shorten his days, destroy his city, abolish his name and memory from the land. Ninlil, 'the mighty mother', shall induce Enlil to decree 'the destruction of his people, the pouring out of his life like water'. Ea, the god of wisdom, shall 'deprive him of knowledge and understanding, and constantly lead him astray, dam up his rivers at the source, take away grain, the life of his people'. Shamash, the sun god and supreme judge, 'may he cause the foundations of his nation to crumble', give evil omens, cut him off from among the living and even 'below, in

\footnotetext{
${ }^{51}$ After Pomponio, op. cit. 23 f. no. I 3.

${ }^{52}$ After Pomponio, op. cit. 3 I ff. no. 28.

${ }^{53}$ Cf. Pomponio, op. cit. $7^{-1} 2$.
} 
the underworld, may he cause his shade to thirst for water'. Sin, the moon god and lord of destiny, shall 'lay upon him heavy guilt' and 'determine as the fate for him a life that is constantly wrestling with death'. ${ }^{54}$ Adad, the lord of abundance, shall bring famine and destructive floods. Zababa and Innana, the deities of war, shall 'let his enemy trample upon him' and 'deliver him into the hands of his enemies'. Nergal, the lord of the underworld, shall 'break his body in pieces like an earthen image'. Nintu, the goddess of birth, shall 'deny him an heir'. Ninkarrak, the goddess of maladies, shall 'inflict upon him a serious injury which never heals, whose nature no physician knows'. Finally, all the gods, and again Enlil, are invoked to 'curse him with these curses'.

I would like to stress three aspects of this text, which illustrate the difference between jurisdiction and imprecation:

(a) The person of the addressee. In the case of Hammurapi, the person involved is specifically a ruler. This shows beyond doubt that the addressee of the curses is not identical with the addressee of the laws. The legal penalty threatens him who transgresses a law, the curses him who alters it. The laws address and concern everybody, but the curses address and concern only future kings, who are responsible for their functioning. The gods are invoked to protect the law, not against a simple trespasser-this protection being provided for by institutionalized 'connective justice'-but against a future ruler of Babylon who might change or neglect the law and thereby weaken connective justice. The ruler's task is to watch over the application of the law, and the god's task is to watch over the ruler.

(b) Concepts of person and annihilation. Penalties aim at restoring the damage which has been done by transgressing a particular rule or law. They are devised to meet and to match a particular crime. Curses, on the other hand, aim at total destruction and annihilation. They do not know any measure and limitation in drawing on the imagery of destruction. They aim at the total dissolution and decomposition of a person in all his aspects, in this world and in the hereafter. In so doing, they provide important insights into the concepts of person involved in these images of destruction. The technique of cursing consists in knowing how to undo a person. It presupposes a concept of person, a knowledge of what constitutes and belongs to a person and how these different elements and constituents are most effectively disintegrated and annihilated.

(c) Prescriptive vs. performative sentences. The Hammurapi code makes the difference between jurisdiction and imprecation absolutely clear. Legislative sentences are prescriptive. They acquire a performative function only when applied by a judge to a given case and transformed into a verdict. Curses, on the other hand, are performative. They do not describe or refer to a fact, but create it. But what they create is a 'potential fact', not an actual one, because they are aimed at a person who is (negatively) specified but not identified. This, by the way, is the defining difference between monuments and treaties, to be considered in the concluding part of this article. Curses in treaties concern persons who are identified, but not (yet) negatively specified. Curses on monuments refer to persons who are negatively specified, but not yet identified.

Treaties provide the most typical context for blessings and curses in ancient Near

\footnotetext{
${ }^{54}$ For curses invoking the moon god Sin, see K. Watanabe, Acta Sumerologica 6 ( I 984 ), 99-I 19.
} 
Eastern texts. Hillers even went so far as to postulate a specific genre of 'treaty-curses' ${ }^{55}$ A covenant, or treaty of alliance, is made, or rather sealed, by swearing an oath. ${ }^{56}$ This conforms to very ancient oriental practice, dating back to the third millennium $\mathrm{BC} .{ }^{57}$ The oath automatically subjects the parties to the powers who watch over the observance of the treaty. Breaking a treaty means breaking an oath and becoming exposed to the curses which are included in and released by swearing an oath. The oldest text of this kind is a boundary stela between the cities of Lagash and Umma. The transgressor is threatened with destruction at the hands of Enlil and Ningirsu, and it is stated that this will occur as political misfortune: his people will deny him obedience and kill him. ${ }^{58}$ The idea of a treaty also differs from that of a law code in that it provides not only penalties but also rewards. Thus we find in many ancient treaties a section containing the typical combination of blessings and cursings. ${ }^{59}$ After the enumeration of the deities by whom the treaty is to be sworn and who are invoked to act as metaphysical agents watching over the observance of the treaty, there follows a list of blessings for him who keeps the treaty and a list of curses for him who breaks it. ${ }^{60}$

Instead of one of the many actual treaties which have survived, and among which the Neo-Assyrian treaties provide the most impressive examples with respect to the 'art' of cursing, ${ }^{61}$ I would like to turn to a text which connects with our own tradition. The Biblical book Deuteronomy has convincingly been shown to be part of the same tradition of ancient oriental diplomacy discussed here, and might even be claimed a particular highlight in the history of the genre. ${ }^{62} \mathrm{It}$ is important in this context in that it mentions two different kinds of blessings and curses, which exactly correspond to the two cases when justice fails, jurisdiction stops and imprecation takes over: secret criminality and breaking of the treaty or deviation from the law..$^{63}$

In chapter 27 it is stated that, after the crossing of the Jordan and the conquest of the Promised Land, stones should be set up on Mount Ebal, covered with plaster and bearing as an inscription the whole text of the Törâ 'in very plain characters' (27.7). Then

${ }^{55}$ D. R. Hillers, Treaty-Curses and the Old Testament Prophets (Rome, I 964); H. C. Brichto, The Problem of 'Curse' in the Hebrew Bible (Philadelphia, I 963). For treaties in general, see now L. Canfora, M. Liverani, C. Zaccagnini (eds.), I Trattati nel Mondo Antico. Forma, Ideologia, Funzione (Rome, I 99o) (I owe this reference to the kindness of K. Deller).

${ }^{56}$ M. Weinfeld, UF 8 (1976), 379-414. H. Tadmor, 'Treaty and Oath in the Ancient Near East: an Historian's Approach', Shnaton 5-6 (1981/2), i 65 ff. (In Hebrew).

${ }^{57}$ P. Artzi, Bar Ilan Studies in History 2 ( 1984 ), 25-39.

${ }^{58}$ F. Thureau-Dangin, Die sumerischen und akkadischen Königsinschriften (Leipzig, I 907), 36 ff.; Pomponio, op. cit. I 7 f., no. I. The treaty between Ebla and A-BAR + SIlA ${ }^{k i}$ (Pomponio, op. cit. 49 f.) might even be somewhat older.

${ }^{59}$ F. C. Fensham, $Z A W 74$ ( I 962$)$, I-9.

${ }^{60}$ Many examples in O. Kaiser (ed.), Texte aus der Umwelt des Alten Testaments, I, fasc. 2. = R. Borger et al., Staatsverträge (Gütersloh, I983). The Assyrian treaties provide an exact model for Deuteronomy, as seen especially by M. Weinfeld, Deuteronomy and the Deuteronomic School (Oxford, 1972).

${ }^{61}$ Cf. S. Parpola, K. Watanabe, (eds.), State Archives of Assyria II: Neoassyrian Treaties and Loyalty Oaths (Helsinki, I988); above all, the vassal treaties of Esarhaddon, for which see Pritchard, op. cit. 534 ff.; Borger et al., Staatsverträge, I6o ff.; R. Frankena, OTS I4 (1965), I 22-54; Parpola and Watanabe, op. cit. 28 ff; Pomponio, op. cit. 50-62.

${ }^{62}$ The affinity of Deuteronomy to the form of a treaty and its many resemblances to political treaties of the ancient Near East has been often observed; see especially Weinfeld, Deuteronomy, I I6 ff., and D. J. McCarthy, Treaty and Covenant (Rome, I 978). See now M. Weinfeld, in L. Canfora, et al. (eds.), I Trattati nel Mondo Antico, I 75-91.

${ }^{63}$ For Biblical forms of cursing, see W. Schottroff, Der altisraelitische Fluchspruch (Neukirchen, I 969). 
six leaders should stand on Mount Gerizim, and six others on Mount Ebal. The former should shout blessings (27.I I-I3) and the latter curses. The ensuing text gives I $_{2}$ verses of curses ( $15^{-26}$ ). The next chapter (28) starts with 14 verses of blessings in case of diligent obedience to the voice of god $\left(3^{-1} 3\right)$, but then again follow no less than 53 verses containing an apparently endless enumeration of elaborate and painful punishments (16-68) for disobedience. It seems that those on Ebal have a task 4 times heavier than those on Gerizim. But a closer analysis reveals that the curses and blessings to be shouted from Ebal are to be distinguished from those of chapter 28. This first set of curses (27.I I-I3) begins with 'cursed be he who (ärûr)', then follows a specific crime. These curses are to be shouted before all the people and the people is to confirm everyone of them by responding 'Amen'; therefore, they are actually self-imprecations and the repeated 'cursed be he' has to be understood as 'cursed shall I be if I.... These are curses which concern undetected or undetectable crimes. ${ }^{64}$ The second set of (blessings and) curses shows an inverse structure. Here, the curse is specified, and the crime consists invariably in not hearkening to the voice of God. These curses refer to the second case: if the treaty is broken and if the law as a whole ceases to be valid among the people. These curses are not to be shouted from Mount Ebal, and not to be confirmed by 'Amen'. They constitute a fact of literature. Their purely literary or rather 'literal' (i.e. written) character is stressed by the text itself, which refers to them as 'the curses of the treaty which are written in the book of the Törâ' (29.20). This points to both their literal and their contractual character. ${ }^{65}$

In this context it is important to remember the prescription that the treaty including the curses and blessings is to be written on stones to be placed on Mount Ebal, the mountain of cursing. This is the point where 'treaty-curses' and 'monument-curses' merge. But the stone which the partners of a treaty set up as a visual sign of the binding force of the contract is not only a monument but also fulfils the function of a 'witness'. This testimonial function is made explicit in the book of Joshua, where the same covenant ceremony as in Deuteronomy is related:

So Joshua made a covenant with the people that day, and set them a statute and an ordinance in Shekhem. And Joshua wrote these words in the book of the Törâ of God, and took a great stone, and set it up there under the oak, that was the sanctuary of the Lord. And Joshua said to all the people, 'Behold, this stone shall be a witness to us; for it has heard all the words of the Lord which he spoke to us: it shall be therefore a witness to you, lest you deny your God.' (Joshua, 24.25-28)

The stones act as witness of the oath by which the treaty is sealed. They materialize, visualize and eternalize the oath.

Curses are part of the religious world-view of ancient oriental society. They do not express 'vague hopes and expectations' but appeal to what must have been believed to be the highest authority and ultimate reality, framing the limited scope of human institutions. Under properly defined and carefully observed circumstances, the spoken word and the monumental inscription were both held capable of reaching beyond that scope into the framing sphere of divine agency. Generally speaking, pharaonic Egypt does not seem to have been an exception. But the particular concept of divine kingship, which in many

\footnotetext{
${ }^{64}$ A. Alt, Kleine Schriften, I, 302-32 (Munich, I 953), 3 I 4.

${ }^{65}$ The literal character of 'treaty-curses' is also stressed by Assurbanipal in one of his historical inscriptions: the gods brought 'the complete number of curses which were laid down in writing' in the record of the treaty over the disloyal Uate' and the Arabs (cf. Pritchard, op. cit. 300a).
} 
respects surpasses comparable conceptions in other oriental societies, might explain why the borderline between jurisdiction and imprecation is sometimes blurred, and why texts like Koptos Decree R and those of Ankhtifi were possible.

Curses and laws are parallel in that both establish a link between crime and punishment, the defining difference being that curses are to be enforced by superhuman powers and laws by legal institutions. In Egypt, the vizier acts as the head of legal institutions, whereas the king already belongs to the superhuman sphere. Curses and oaths, on the other hand, are parallel in that both invoke the divine sphere, but in a different way. Curses request intervention, they are to be fulfilled by the superhuman powers invoked. Oaths request supervision, they are to be fulfilled by the people swearing. There is also the evident parallel between cursing and blessing. Both invoke divine intervention, one in punishing, the other in rewarding, intention. Curses, blessings and oaths are oral acts of legally binding character. This explains their strong affinity to legislation and jurisdiction. But their functioning does not depend on police and law-courts but on the belief in 'metaphysical agency'. 